\title{
Pseudotumoral Actinomycosis Mimicking Malignant Colic Disease: A Case Report and Literature Review
}

\author{
Rachid Jabi $^{a}$ Hanae Ramdani ${ }^{b}$ Siham Elmirc Fouad Elmejjati ${ }^{\mathrm{d}}$ Badr Serji $^{\mathrm{a}}$ \\ Tijani El Harroudi ${ }^{a} \quad$ Mohammed Bouziane $^{a}$ \\ ${ }^{a}$ General Surgery Department, Faculty of Medicine and Pharmacy, Mohammed VI University Hospital, Oujda,

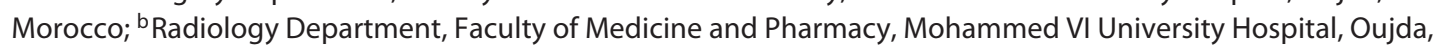 \\ Morocco; ' Department of Physical Medicine and Rehabilitation, Faculty of Medicine and Pharmacy, Mohammed VI

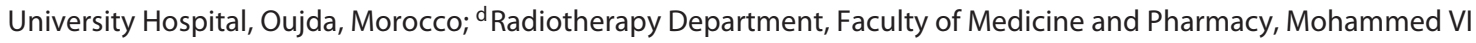 \\ University Hospital, Oujda, Morocco
}

Keywords

Actinomycosis $\cdot$ Pseudotumoral syndrome $\cdot$ Colon

\begin{abstract}
Abdominal actinomycosis is a rare, chronic, and often unrecognized suppurative disease. It is caused by an anaerobic gram-positive bacterium, most commonly Actinomyces israeli. Colonic actinomycosis is rarely reported and may be responsible for a pseudotumoral syndrome leading, in the suspicion of malignancy, to a large and mutilating excisional surgery. It is usually the histopathological examination of the surgical specimens that accurately corrects the diagnosis. Here, we report a rare case of a colic actinomycotic involvement taking a pseudotumoral form. The diagnosis was made based on the pathological examination of the surgical piece. Intravenous and then adjuvant oral penicillin $\mathrm{G}$ treatment has allowed a favorable clinical evolution. This observation illustrates the preoperative diagnostic difficulties of this rare disease.

() 2019 S. Karger AG, Base
\end{abstract}

\section{Introduction}

Actinomycosis is a rare granulomatous, suppurative, and fibrotic chronic infectious disease caused by Actinomyces [1]. The latter are gram-positive, anaerobic bacilli, represented in $85 \%$ of cases by Actinomyces israelii [1]. Actinomyces are part of the commensal flora of the oropharynx, the digestive tract, and occasionally the vagina. The most frequent locations are respectively, cervicofacial (55\%), abdominal (20\%), and thoracic (15\%) [2-5]. Actinomycosis can sit anywhere in the abdominal cavity but predominates in the ceco-appendicular region [6-8] and extends to surrounding structures across fascia and connective tissues. Moreover, the infiltrative and aggressive patterns are very indicative of actinomycosis. The left side of the colon is rarely reported to be affected [9]. Actinomycosis is not very virulent but may become pathogenic after breaking of the intestinal mucosal barrier (trauma, surgical procedure, or infection) $[2,10-13]$ or weakening of tissue resistance (immunodepression, diabetes, or corticosteroid therapy) [14]. Diagnosis of actinomycosis in our patient was made after histological analysis of the operative specimen. Here, we report a rare case of colic pseudotumoral actinomycosis. 


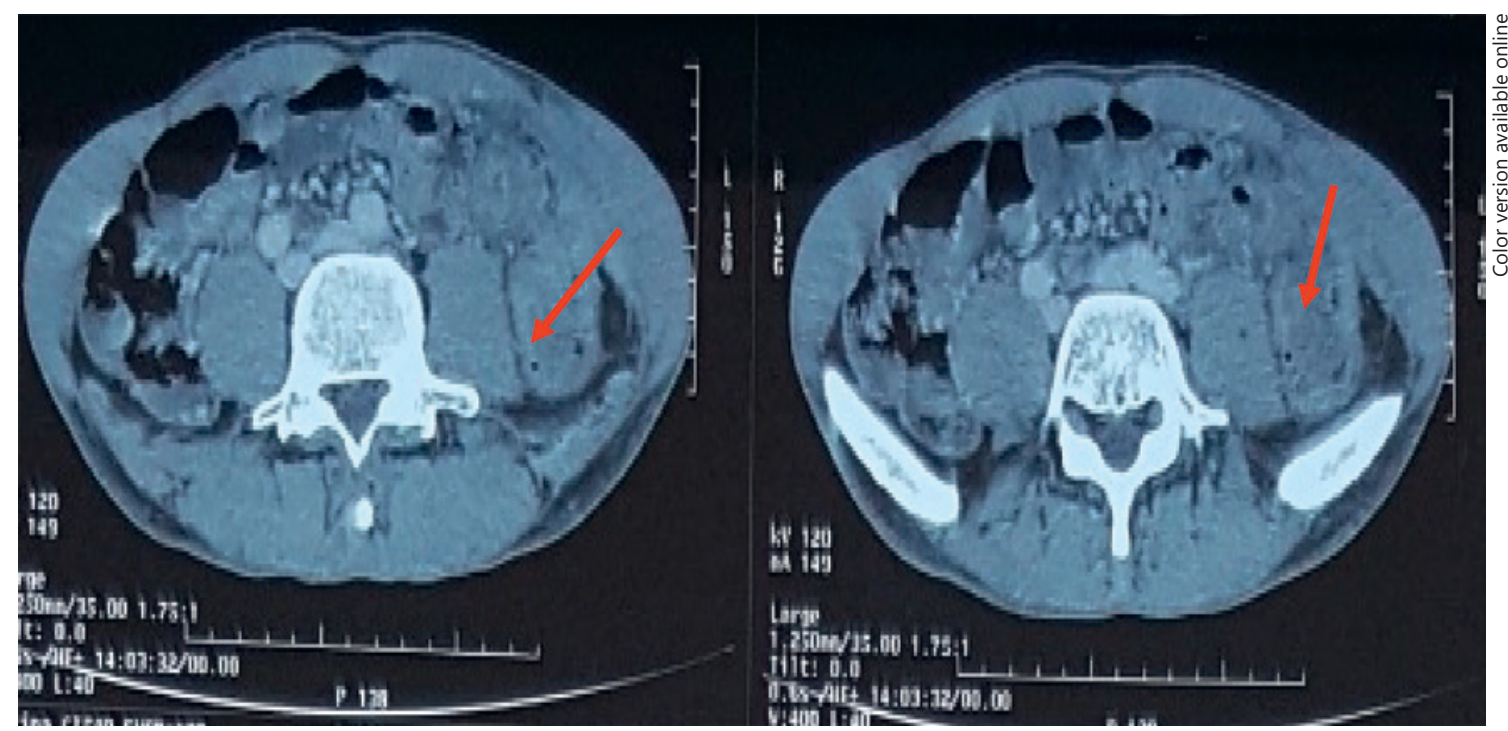

Fig. 1. Irregular thickening of the descending colon with infiltration of the wall.

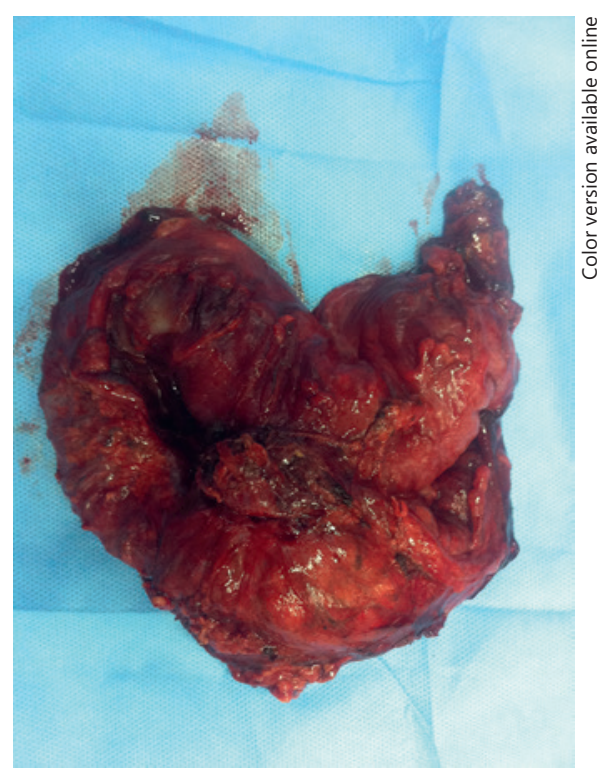

Fig. 2. Abscessed tumor of the left colon found during segmental carcinologic colectomy.

\section{Case Presentation}

A 48-year-old male patient native and living in eastern Morocco presented with a 3 -week history of left iliac fossa pain and mass with a general health state deterioration and fever $\left(38^{\circ} \mathrm{C}\right)$. The clinical examination found a sensitive left iliac fossa mass. Colonoscopy showed a prestenotic sigmoidal zone with pseudopolyps. The results of the biopsy were in favor of congestive colitis with neither a tuberculoid granuloma nor an abscess or suspicious elements. Blood tests showed a slightly increased WBC count $\left(11,070 / \mathrm{mm}^{3}\right)$ and a C-reactive protein of $53.08 \mathrm{mg} / \mathrm{L}$. Basic abdominal X-ray showed air-fluid levels, whereas abdominal computed tomography (CT) scan revealed an irregular thickening of the descending colon with infiltration of its wall (Fig. 1). Surgical exploration found an abscessed tumor of the left colon. A carcinologic left segmental colectomy with latero-lateral mechanical anastomosis was performed (Fig. 2). The intervention went well and was tolerated by the patient without any unwanted adverse events. The histopathological examination was in favor of colonic actinomycosis (Fig. 3). The postoperative course was without incident. Penicillin-based oral therapy (amoxicillin 2 g/day) for 6 months allowed a complete cure.

\section{Discussion}

Abdomino-pelvic actinomycosis is rare and its diagnosis is often difficult and delayed. It was nicknamed the "great simulator" because of the lack of specificity of its symptoms [14]. Indeed, the onset is insidious and progressive, associated with a general state of deterioration, an infectious syndrome, and a pseudotumoral syndrome $[2,11]$, which can simulate cancer, tuberculosis, or Crohn's disease. These pseudotumoral masses can progress towards abscess formation with a risk of secondary rupture and fistulization. The most serious complication is peritonitis due to rupture of an abscess [2]. In our case, the symptomatology was in favor of colon cancer which led us to carry out a carcinologic excision. In actinomycosis, biology is not very contributive and usually consists of a marked inflammatory syndrome $[2,11]$. Colonoscopy is generally not helpful in diagnosis when the disease is of an extramucosal origin. Furthermore, endoscopy plays a significant role in excluding colitis or malignant disease and revealing a lumen narrowing or parietal stiffness [15]. Radiological examinations (ultrasound, barium enema, and CT) are not specific $[2,11$, 

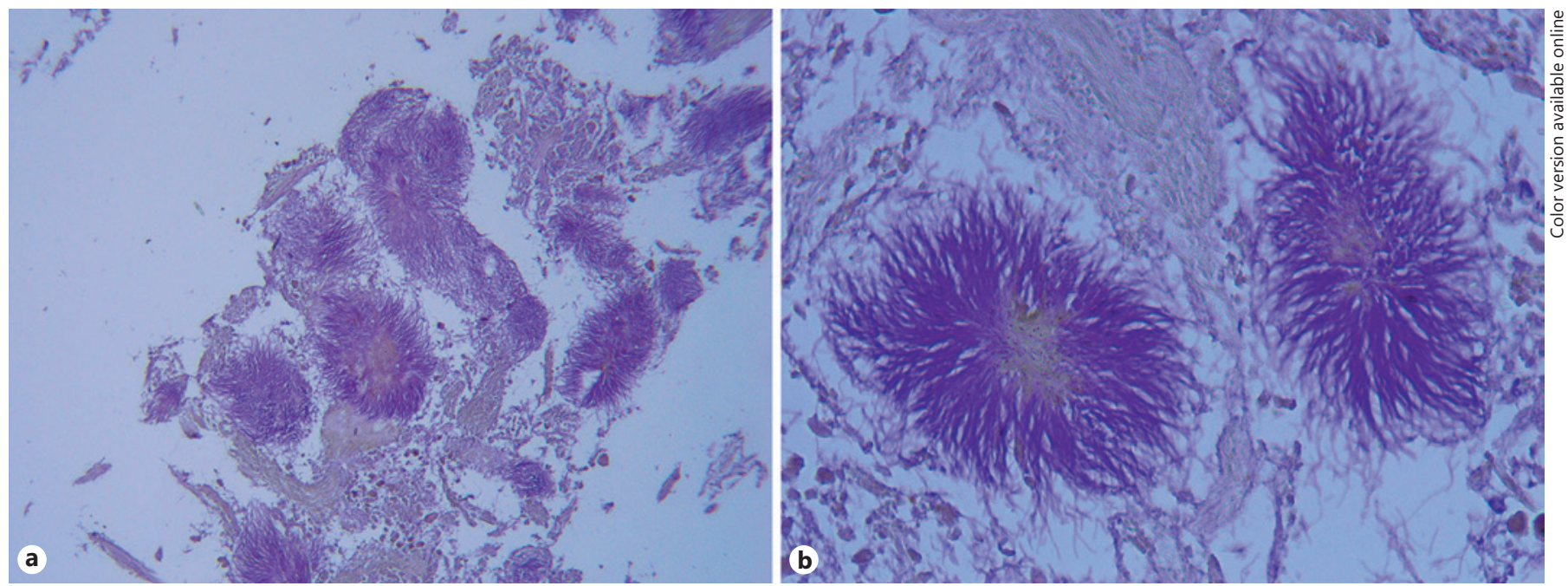

Fig. 3. a Numerous bacterial colonies found at the center of a fibrinous tissue. b Bacterial colonies with basophilic radiating filaments which are a key feature of actinomycosis.

16]. However, CT scan may help in characterizing masslike structures. Its common finding is concentric bowel wall thickening, associated with an adjacent cystic or solid mass surrounded by prominent inflammatory infiltrations [17]. Solid portions of the mass and soft-tissue strands around it enhance strongly following contrast material injection. The aggressive nature of the mass is suggestive of a tumor. However, regional lymph nodes are rarely present [15]. Although the infiltrative nature of abdominal actinomycosis is unrestricted, it is unlikely to spread into the entire peritoneal cavity. Ascites are usually minimal or absent [17]. CT can also demonstrate a pseudotumor appearance that does not respect tissue limits [15].

Bacteriological diagnosis is possible, and the bacteriologist should be warned about the suspicion of actinomycosis. The culture performed under anaerobic conditions in a $\mathrm{CO}_{2}$-rich atmosphere and can only be positive in about $50 \%$ of cases [2]. Importantly, the definitive diagnosis may only be possible based on the pathological examination of the surgical specimens on the basis of the characteristic finding of "sulfur granules," which represent tangled filaments of Actinomyces species (named for their yellow color) $[15,18]$. Special staining such as Gomori methenamine silver can be used to illustrate the composition of sulfur granules such as branching bacteria and not fungi, cocci, or bacilli as they may occur in other infectious diseases such as eumycetoma and nocardiosis $[12,19,20]$. The extemporaneous examination sometimes makes it possible to correct the diagnosis, thus avoiding large, difficult, and useless excisions [11, 19]. Notably, other differential diagnoses such as cancer, tuberculosis, Crohn's disease, amoebiasis, or appendici- tis are to be considered in such cases $[3,21]$. The treatment is mainly based on intravenous penicillin antibiotics, with oral relay for 6-12 months to prevent recurrence $[16,22]$. In practice, surgery is often a diagnostic step [19, 22 ] and it should be indicated in cases of acute presentations such as appendicular peritonitis, obstruction, or abscess perforation. Prognostic outcomes in colic actinomycosis remain serious in the absence of treatment, but the disease evolves well in cases of early diagnosis and adapted treatment (Table 1). Immunodepression is an adverse prognostic factor for actinomycosis evolution under different therapies [9]. Actinomycosis is a diagnostic challenge; it is often unrecognized and frequently confused with a malignant or chronic granulomatous disease [12]. Although clinical, biological, and radiological features are not specific, actinomycosis should be considered in the case of any abdominal mass that presents a highly infiltrative nature, strong enhancement CT scan, and suppurative necrosis. Notably, the pseudotumoral aspect of a colonic mass with a mucosa of normal aspect on endoscopy should alert the clinician of this rare entity. Actinomycosis diagnosis confirmation is based on histopathological examination. Penicillin $G$ is the drug of choice and should be the first line of treatment in mild forms of the disease. For persistent disease and complicated cases, combined medical and surgical treatment may be considered, such as in our case. In any colonic mass with negative endoscopy, actinomycosis must always be considered with other malignant and inflammatory etiologies. 
Table 1. Summary of large studies and literature reviews regarding treatment outcomes of pseudotumoral actinomycosis

\begin{tabular}{|c|c|c|c|c|}
\hline Author/year & Country & Study type & $n$ & Management and main findings \\
\hline $\begin{array}{l}\text { Târcoveanu } \\
\text { et al. [23], } 2019\end{array}$ & Romania & $\begin{array}{l}\text { Retrospective } \\
\text { cohort }\end{array}$ & 13 & $\begin{array}{l}\text { - Preoperative diagnosis is established in less than } 10 \% \text { of cases and can } \\
\text { avoid surgery } \\
\text { - The clinical presentation is similar to that of chronic inflammatory and } \\
\text { malignant diseases } \\
\text { - Laparotomy or laparoscopy + intravenous penicillin therapy (2-6 } \\
\text { weeks) followed by } 6 \text { months of oral penicillin is recommended } \\
\text { - Postsurgery follow-up is required as relapse is possible }\end{array}$ \\
\hline
\end{tabular}

\begin{tabular}{|c|c|c|c|c|}
\hline $\begin{array}{l}\text { Wacharachaisurapol } \\
\text { et al. [7], } 2017\end{array}$ & Thailand & $\begin{array}{l}\text { Case report } \\
\text { and review of } \\
18 \text { previous } \\
\text { cases }\end{array}$ & 19 & $\begin{array}{l}\text { - Abdominal pain and lump/mass dominate the clinical presentation } \\
\text { mimicking malignant tumors } \\
\text { - The majority of reported cases required exploratory surgery } \\
\text { - Penicillin use is the gold standard for postoperative parenteral treatment }\end{array}$ \\
\hline $\begin{array}{l}\text { García-García } \\
\text { et al. [13], } 2017\end{array}$ & Mexico & $\begin{array}{l}\text { Systematic } \\
\text { review }\end{array}$ & 86 & $\begin{array}{l}\text { - Intrauterine device may be incriminated in the pathogenesis of this en- } \\
\text { tity and must be changed regularly } \\
\text { - Diagnosis is often made after postsurgical interventions } \\
\text { - Actinomycosis is confused with chronic inflammatory lesions and tu- } \\
\text { mors } \\
\text { - The presence of clinical symptoms is often associated with advanced dis- } \\
\text { ease stages }\end{array}$ \\
\hline $\begin{array}{l}\text { Lisa-Gracia } \\
\text { et al. [10], } 2017\end{array}$ & Spain & $\begin{array}{l}\text { Prospective } \\
\text { cohort }\end{array}$ & 13 & $\begin{array}{l}\text { - Risk factors for appendiceal actinomycosis include no antecedents of } \\
\text { carcinoma }(p=0.034) \text { and previous incorrect diagnosis }(p=0.006) \\
\text { - As expected, appendiceal actinomycosis has a very variable and nonspe- } \\
\text { cific clinical presentation and surgery was offered to all patients with good } \\
\text { evolution }\end{array}$ \\
\hline $\begin{array}{l}\text { Pierre } \\
\text { et al. [9], } 2014\end{array}$ & France & $\begin{array}{l}\text { Retrospective } \\
\text { cohort }\end{array}$ & 33 & $\begin{array}{l}\text { - Immunosuppression in immunocompromised patients with invasive } \\
\text { actinomycosis significantly predicts poor outcomes in this population } \\
(p=0.027)\end{array}$ \\
\hline $\begin{array}{l}\text { Sung } \\
\text { et al. [24], } 2011\end{array}$ & $\begin{array}{l}\text { South } \\
\text { Korea }\end{array}$ & $\begin{array}{l}\text { Retrospective } \\
\text { cohort }\end{array}$ & 23 & $\begin{array}{l}\text { - } 50 \% \text { of the patients presented to the emergency department with symp- } \\
\text { toms of peritonitis } \\
\text { - Included subjects commonly had preoperative computerized tomogra- } \\
\text { phy findings in favor of masses with abscess and malignancy behavior } \\
\text { - Best results are achieved by combining short-term antibiotic therapy } \\
\text { and surgical resection } \\
\text { - No recurrence was seen after } 30 \text { months of clinical follow-up }\end{array}$ \\
\hline $\begin{array}{l}\text { Choi } \\
\text { et al. [25], } 2009\end{array}$ & $\begin{array}{l}\text { South } \\
\text { Korea }\end{array}$ & $\begin{array}{l}\text { Retrospective } \\
\text { cohort }\end{array}$ & 22 & $\begin{array}{l}\text { - } 60 \% \text { of patients had intrauterine device } \\
-50 \% \text { of patients benefited from surgery because of peritonitis } \\
\text { - Only } 2 \text { patients had features of malignant colon tumors } \\
\text { - Definitive diagnosis could not be made based on radiological findings } \\
\text { - Penicillin IV is the treatment of choice for a period of 3-6 months after } \\
\text { surgical removal }\end{array}$ \\
\hline
\end{tabular}

\section{Statement of Ethics}

Written informed consent was obtained from the patient for publication of this case report. CARE guidelines were applied for reporting this case report finding.

\section{Disclosure Statement}

The authors declare no conflict of interest.

\section{References}

1 Wong VK, Turmezei TD, Weston VC. Actinomycosis. BMJ. 2011 Oct;343:d6099.

2 Boyanova L, Kolarov R, Mateva L, Markovska R, Mitov I. Actinomycosis: a frequently forgotten disease. Future Microbiol. 2015;10(4): 613-28.

3 Kacem C, Puisieux F, Kammoun A, Morched $\mathrm{AM}$, Zaouche A. [Abdominal actinomycosis.
Report of three cases and review of the literature]. Ann Med Interne (Paris). 2000 Jun; 151(4):243-7. French.

4 Privitera A, Milkhu CS, Datta V, RodriguezJusto M, Windsor A, Cohen CR. Actinomycosis of the sigmoid colon: A case report. World J Gastrointest Surg. 2009 Nov;1(1) $62-4$. 
5 Pusiol T, Morichetti D, Pedrazzani C, Ricci F. Abdominal-pelvic actinomycosis mimicking malignant neoplasm. Infect Dis Obstet Gynecol. 2011;2011:747059.

6 Kim SY, Lee SK, Moon SB. Abdominal actinomycosis complicated by delayed splenic abscess. Surg Infect (Larchmt). 2014 Oct; 15(5):662-4.

7 Wacharachaisurapol N, Bender JM, Wang L, Bliss D, Ponrartana S, Pannaraj PS. Abdominal Actinomycosis in Children: A Case Report and Literature Review. Pediatr Infect Dis J. 2017 Mar;36(3):e76-9.

8 Valko P, Busolini E, Donati N, Chimchila Chevili S, Rusca T, Bernasconi E. Severe large bowel obstruction secondary to infection with Actinomyces israelii. Scand J Infect Dis. 2006; 38(3):231-4.

9 Pierre I, Zarrouk V, Noussair L, Molina JM, Fantin B. Invasive actinomycosis: surrogate marker of a poor prognosis in immunocompromised patients. Int J Infect Dis. $2014 \mathrm{Dec}$; 29:74-9.

10 Lisa-Gracia M, Martín-Rivas B, PajarónGuerrero M, Arnáiz-García A. Abdominal actinomycosis in the last 10 years and risk factors for appendiceal actinomycosis: review of the literature. Turk J Med Sci. 2017 Feb;47(1): 98-102.

11 Noomene F, Zouari K, Kallel W, et al. Abdominal actinomycosis: 3 observations. Presse Med. 2003;32:698700.
12 Vialle R, Bernier M, L'helgouarc'h JL, Huerre M, Attal E, Frileux P. [Colonic actinomycosis. Clinical, endoscopic and pathological aspects of one patient]. Gastroenterol Clin Biol. 2001 Oct;25:908-11. French.

13 García-García A, Ramírez-Durán N, Sandoval-Trujillo $\mathrm{H}$, Romero-Figueroa MD. Pelvic Actinomycosis. Can J Infect Dis Med Microbiol. 2017;2017:9428650.

14 Sehnal B, Beneš J, Kolářová Z, Mojhová M, Zikán M. Pelvic actinomycosis and IUD. Ceska Gynekol. 2018;83(5):386-90.

15 Kim JC, Ahn BY, Kim HC, Yu CS, Kang GH, $\mathrm{Ha} \mathrm{HK}$, et al. Efficiency of combined colonoscopy and computed tomography for diagnosis of colonic actinomycosis: a retrospective evaluation of eight consecutive patients. Int J Colorectal Dis. 2000 Aug;15(4):236-42.

16 Rose G, Franke FE, Weimar B, Buhr J, Padberg $\mathrm{W}$. [Actinomycosis of the colon as a rare differential diagnosis of colonic carcinoma]. Chirurg. 2000 Jan;71(1):93-7. German.

17 Heo SH, Shin SS, Kim JW, Lim HS, Seon HJ, Jung SI, et al. Imaging of actinomycosis in various organs: a comprehensive review. Radiographics. 2014 Jan-Feb;34(1):19-33.

18 Ferrari TC, Couto CA, Murta-Oliveira C, Conceição SA, Silva RG; T. C. A. Ferrari, C. A. Couto, C. M. Actinomycosis of the colon: a rare form of presentation. Scand J Gastroenterol. 2000 Jan;35(1):108-9.
19 Smego RA Jr, Foglia G. Actinomycosis. Clin Infect Dis. 1998 Jun;26(6):1255-61.

20 Tlili-Graiess K, Arifa-Achour N, Mrad Dali K, Sriha B, Dahmen Y, Bakir D, et al. [Abdominal actinomycosis. Report of 4 clinical cases studied with radiography]. J Radiol. 2001 Jan; 82(1):67-72. French.

21 Baraket O, Itaimi A, Triki W, Moussa M Ayed K, Ben Hmida S, et al. [Therapeutic and diagnostic difficulties of abdominal actinomycosis: about one case in a Tunisian female patient]. Bull Soc Pathol Exot. 2016 May; 109(2):84-6. French.

22 Russo TA. Agents of actinomycosis. In: Mandell GL, Bennett JE, Dolin R, editors. Mandell, Douglas, and Bennett's principles and practice of infectious diseases. 7 th ed. Philadelphia (Pa): Churchill Livingstone Elsevier; 2010.pp. 3209-19.

23 Târcoveanu E, Vasilescu A, Andronic D, Lupaşcu C, Ciobanu D, Vlad N, et al. Abdominal Actinomycosis Mimicking Colon Cancer. Chirurgia (Bucur). 2019 Mar-Apr;114(2): 251-8.

24 Sung HY, Lee IS, Kim SI, Jung SE, Kim SW, Kim SY, et al. Clinical features of abdominal actinomycosis: a 15-year experience of a single institute. J Korean Med Sci. 2011 Jul;26(7): 932-7.

25 Choi MM, Baek JH, Lee JN, Park S, Lee WS. Clinical features of abdominopelvic actinomycosis: report of twenty cases and literature review. Yonsei Med J. 2009 Aug;50(4):555-9. 